\title{
Girişimcilik Yönelimi İle Finansal Performans Arasındaki İlişkide Araştırma ve Geliştirme (AR-GE) Kapasitesinin Aracı Rolü Üzerine Bir Araştırma: İstanbul ve Kocaeli Bölgesi Örneği
}

Fahrettin PALA ${ }^{1}$

\begin{tabular}{ccc}
\hline $\begin{array}{c}\text { Geliş Tarihi/ Received } \\
\text { 28/08/2020 }\end{array}$ & Kabul Tarihi/ Accepted & Yayın Tarihi/ Published \\
$12 / 01 / 2021$ & $15 / 04 / 2021$ \\
\hline Citation/Atıf: Pala, F., (2021), Girişimcilik Yönelimi İle Finansal Performans Arasındaki \\
İlişkide Araştırma ve Geliştirme \\
Istanbul ve Kocaeli Bölgesi Örneği, Atatürk Üniversitesi İktisadi ve İdari Bilimler Dergisi, \\
35(2): Sayfa: 497-521, https://doi.org/10.16951/atauniiibd.786989 \\
\hline
\end{tabular}

Öz: Çalışmanın amacı, girișimcilik yöneliminin finansal performans üzerindeki etkisinde Araştırma ve Geliştirme (AR-GE) kapasitesinin aracı rolünün olup olmadığının Yapısal Eşitlik Modeli (YEM) ile araştırılmasıdır. $\mathrm{Bu}$ amaç doğrultusunda anket yöntemiyle işletme yöneticilerinden elde edilen toplam 130 verinin analizinde Yapısal Eşitlik Modeli (YEM) kullanılmıştır. AR-GE kapasitesinin aracı değişken olarak kullanıldığı analizde, analiz sonuçları girişimcilik yöneliminin finansal performans üzerinde direkt etkisinin olmadığını, ancak AR-GE kapasitesi üzerinden dolaylı olarak etkisini doğrulamıştır. Ayrıca AR-GE kapasitesi ile uluslararası deneyimin finansal performans üzerinde direkt etkisini doğrularken, firma yaşının finansal performans üzerindeki etkisine destek sağlamamıştır.

Anahtar Kelimeler: Girişimcilik Yönelimi, Finansal Performans ve PLS-SEM

A Research on the Mediating Role of Research and Development (R\&D) Capacity in the Relationship between Entrepreneurship Orientation and Financial Performance: Istanbul and Kocaeli Region Example

Abstract: The aim of this study is to investigate whether the Research and Development $(R \& D)$ capacity has a mediator role in the impact of entrepreneurship orientation on financial performance by using the Structural Equation Model (SEM). For this purpose, the Structural Equation Model (SEM) was used in the analysis of 130 data obtained from the business managers through the survey method. In the analysis where $R \& D$ capacity is used as a mediator variable, the results of the analysis confirmed that entrepreneurship orientation does not have a direct effect on financial performance, but indirectly through its $R \& D$ capacity. In addition, while the $R \& D$ capacity and international experience confirmed the direct effect of the financial performance, the firm did not support the effect of its age on financial performance.

Keywords: Entrepreneurship Orientation, Financial Performance, PLS-SEM

JEL Codes: G30, M13, M20

${ }^{1}$ Dr. Öğr. Üyesi. Gümüşhane Üniversitesi, Kelkit Aydın Doğan Meslek Yüksek Okulu, Muhasebe veVergi Bölümü, pala_tr1980@hotmail.com,https://orcid.org/0000-0001-9565-8638 
T Girişimcilik Yönelimi Ile Finansal Performans Arasındaki Ilişkide Araştırma ve Geliştirme (AR-GE) Kapasitesinin Aracı Rolü Üzerine Bir Araştırma: Istanbul ve Kocaeli Bölgesi Örneği

\section{EXTENDED SUMMARY}

\section{Research Problem}

The aim of this study is to investigate whether the Research and Development (R\&D) capacity has a mediator role in the impact of entrepreneurship orientation on financial performance by using the Structural Equation Model (SEM).

\section{Research Questions} performance?

Does entrepreneurship orientation directly influencing financial

Does innovation, one of the entrepreneurship orientation dimensions, directly effective on financial performance?

Does proactivity, one of the entrepreneurship orientation dimensions, directly effective on financial performance?

Does risk taking, one of the entrepreneurship orientation dimensions, directly effective on financial performance?

Does entrepreneurship orientation indirectly affect financial performance through R\&D capacity?

Does innovation, one of the entrepreneurship orientation dimensions, indirectly affect financial performance through R\&D capacity?

Does proactivity, one of the entrepreneurship orientation dimensions, indirectly affect financial performance through R\&D capacity?

Does risk taking, one of the entrepreneurship orientation dimensions, indirectly affect financial performance through R\&D capacity?

\section{Literature Review}

The purpose of the literature search is to determine the direct effect between the researched entrepreneurial orientation and financial performance or the indirect effect between these two variables through $R \& D$ capacity. To reveal the gaps and skips in the literature in this area and to determine where our own study will fit in the previous literature. In this direction, the literature has been examined under two main headings. First, the studies investigating the effects of entrepreneurship orientation and its dimensions on financial performance were examined, and secondly, studies investigating the effects of R\&D investments / expenditures on financial performance were examined. The literature generally shows that the effect of entrepreneurship orientation and $\mathrm{R} \& \mathrm{D}$ expenditures on financial performance is significant and positive.

\section{Methodology}

In the study, questionnaire technique was used as a data collection tool because of its features of obtaining standard data and presenting superior data analysis. A total of 210 manufacturing companies operating in Istanbul and Kocaeli regions were included in the sample, 194 of which were reached. 130 of these companies reached returned, and all the surveys returned were included in the study. Reliability and validity analysis of the scales are important for the continuation of the research. Accordingly, Cronbach's Alpha and rho_A values 
were used for the internal consistency reliability of the scales. Composite Reliability / CR value is used for combined reliability. For the purpose of the research, variance-based PLS-SEM approach, one of the structural equation models, was used to test the hypotheses developed in parallel with the literature.

\section{Results and Conclusions}

The results of the analysis revealed that there is a significant and positive relationship between $R \& D$ capacity, proactivity and international experience and financial performance. When the role of R\&D capacity in the relationship between entrepreneurship orientation lengths and financial performance is analyzed, it's has been determined that proactivity and innovation have a significant and positive effect on financial performance through R\&D capacity.

This shows that R\&D capacity has an intermediary role in the relationship between entrepreneurship orientation and financial performance. The limitations of the study were the fact that the business managers within the scope of the research do not accept the requests for face-to-face meetings, their reluctance to answer the surveys and the do not provision of data related to financial performance criteria.

With the findings obtained, it can be said that the R\&D capacity has an intermediary role between entrepreneurship orientation and financial performance. This shows that business managers should make strategic plans related to R\&D and put innovation at the center of these plans.

Likewise, it shows that policy makers should pay more attention to the issue of R\&D incentives. Because new products and services emerging as a result of R\&D activities; it will cause an increase in production and exports and a decrease in imports. Therefore, to reduce the foreign trade deficit and current account deficit, especially in developing one of the greatest obstacles to Turkey and will results in substantial increase in foreign exchange reserves.

Since this study is thought to be important for guiding future studies, the following suggestions can be given to research.

$\checkmark$ The study can be conducted in the different regions or provinces in order to generalize the research results.

$\checkmark$ Research has been applied to medium and large business managers and research can be done on SMEs.

$\checkmark \quad$ In order for the research to be universal, the level of development can be done by comparing different countries and/or continents.

$\checkmark$ It can be added to the research in different variables and evaluated more comprehensively.

\section{Giriş}

Günümüz ekonomi ve iş dünyası yoğun rekabet ortamında hayatlarını devam ettirmek durumunda kalmışlardır. Özellikle küreselleşme, serbestleşme, 
T Girişimcilik Yönelimi Ile Finansal Performans Arasındaki Ilişkide Araştırma ve Geliştirme (AR-GE) Kapasitesinin Aracı Rolü Üzerine Bir Araştırma: Istanbul ve Kocaeli Bölgesi Örneği

yeni teknoloji ve e- ticaret gibi unsurlar nedeniyle bu rekabet ortamı daha da artmış ve zorlaşmıştır. İşletmelerin bu yoğun rekabet ortamlarında mevcut pazar paylarını koruyarak varlıklarını devam ettirebilmelerinin inovasyona bağlı olduğu bilinmektedir. İnovasyonun gerçekleşmesi ise AR-GE faaliyetlerine bağlıdır. Başka bir ifadeyle inovasyonun ön koşulu AR-GE faaliyetleridir. ARGE faaliyetleri sonucu ortaya çıkan yenilikçi yaklaşımlar girişimci bakış açısıyla değerlendirilerek ticarileştirildiğinde inovasyon ortaya çıkar (MÜSİAD, 2012: 56). Küreselleşme ile birlikte artan yoğun rekabet ortamında gerek ürün ve hizmetlerin üretiminde gerekse üretim süreçlerinin geliştirilerek iyileştirilmesinde AR-GE faaliyetlerinden yararlanılması yenilikçi organizasyon yapıları açısından rekabet avantajı haline gelmiştir (Aygen, 2006: 10).

Bir diğer rekabet avantajı unsuru da girişimcilik yönelimi ve unsurlarıdır. Girişimci yönelimine sahip firmalar, yeni ve belirsiz ürünleri, hizmetleri ve pazarları denemek için risk almak, yeni pazar firsatları için rakiplerinden daha proaktif olmak için yenilik yapmaya isteklidirler (Wiklund ve Shepherd, 2005: 75). Girişimcilik yönelimi, işletmeleri rakiplerinden ayırabilecek ve rekabet avantajı yaratacak yeni firsatları bulma ve / veya keşfetme olanağı sağlar (Wiklund ve Shepherd, 2005: 72).

AR-GE faaliyetlerinin işletmeler açısından bu denli önemli olduğu günümüz dünyasında bu çalışmanın yapılması önem arz eden bir konudur. Aynı şekilde literatürde var olan çalışmaların tamamına yakınında, girişimcilik yöneliminin ve/veya AR-GE kapasitesinin farklı bağımlı değişkenler üzerindeki etkilerini teorik ve ampirik olarak inceleyen çalışmalar olduğu tespit edilmiştir. $\mathrm{Bu}$ çalışma diğerlerinden farklı olarak girişimcilik yönelimi ve finansal performans arasındaki ilişkide AR-GE kapasitesinin aracı rolünü incelemesi nedeniyle özgün bir çalışma olduğu düşünülmekte ve bu anlamda literatüre katkı sağlaması beklenmektedir.

İşletmeler açısından hayati öneme sahip olan girişimcilik ve ARGE faaliyetleri özellikle gelişmekte olan ülke Türkiye açısından önem arz ettiğinden dolayı bu çalışma yapılmıştır. Çalışmanın amacı, girişimcilik yöneliminin finansal performans üzerindeki etkisinde Araştırma ve Geliştirme (AR-GE) kapasitesinin aracı rolünün olup olmadığının Yapısal Eşitlik Modeli (YEM) ile araştırılmasıdır. Bu amaç doğrultusunda çalışma altı bölümden oluşmaktadır. Birinci bölümde giriş kısmı açıklandıktan sonra ikinci bölümde kavramsal çerçeve açıklanmıştır. Üçüncü bölümde literatür taraması yapılmıştır. Dördüncü bölümde araştırmanın metodoloji kısmı açıklanmıștır. Beşinci bölümde analiz ve bulgular kısmı açıklandıktan sonra altıncı ve son bölümde ise sonuç ve öneriler kısmına yer verilerek çalışma tamamlanmıştır. 


\section{Kavramsal Çerçeve}

\subsection{Girişimcilik Yönelimi}

1971 yılında Peterson ve Berger'in yapmış olduğu öncü çalışmadan sonra girişimcilik yönelimi kavramı akademik yazında hızlı bir şekilde gelişen araştırma konusu olmuştur (Fiş ve Wasti, 2009: 131). Bu kavram Millerin (1983) yıllında yapmış olduğu örgüt düzeyindeki girişimcilik araştırması ile başlamış, Covin ve Slevin'in $(1989,1990)$ yıllarındaki çalışmaları ile ilerletilmiş ve Lumpkin ve Dess'in (1996) yılında yapmış olduğu çalışma ile de geliştirilmiştir (Solmaz, 2016: 17-18). Covin ve Slevin (1989), girişimcilik yönelimi kavramını, yeni bir teşebbüse/girişime yönlendiren süreçler, uygulamalar ve karar verme faaliyetleri olarak tanımlamışlardır (Covin ve Sleven, 1989'dan aktaran; Platin ve Ergun, 2017). Lumpkin ve Dess (2001) ise, yeni ürünlerin ortaya koyulmasından, rekabet avantajı sağlayacak stratejilerin belirlenmesine ve belirlenen bu stratejilerin uygulamaya geçirilmesine kadarki tüm yeteneklerin toplamı olarak tanımlamışlardır. Girişimcilik yönelimi, işletmelere rakipleri karşısında teknik üstünlükler sağlayacak rekabet avantajı yaratarak onlara yeni firsatları bulma, keşfetme imkanı sağlar (Wiklund ve Shepherd, 2005: 72).

\subsubsection{Girişimcilik Yönelimi Boyutları}

Miller (1983) yılında yapmış olduğu çalışmasında girişimcilik boyutlarını; yenilik, proaktiflik ve risk alama olarak ifade etmiştir. Covin ve Slevin (1991) yılında yapmış oldukları çalışmalarında girişimcilik yönelimi boyutları olarak yenilik, proaktiflik ve risk alma boyutlarını kullanmışlardır. Lumpkin ve Dess (2001) çalışmalarında girişimcilik yönelimi fonksiyonun çok boyutlu olduğunu ifade ederek, bu boyutların yenilikçilik, proaktiflik, risk alma, özerklik ve rekabetçi saldırganlık olduğunu belirtmişlerdir. Yapılan literatür değerlendirmesi sonucunda girişimcilik yönelimi boyutları ile ilgili yaygın olarak kullanılanların yenilikçilik, proaktiflik ve risk alma olduğu tespit edilmiştir. Çalışmada da literatüre paralel olarak yenilikçilik, proaktiflik ve risk alma boyutları kullanılmıştır.

\subsubsection{Yenilikçilik}

Yenilikçilik firmaların büyümesini sağlayan en önemli belirleyicidir (Brüdel ve Preisendörfer, 2000: 67). Lumpkin ve Dess (1996) yenilikçiliği, bir firmanın yeni ürün, hizmet veya teknolojik sürecine neden olabilecek yaratıcı düşünceleri, deneyleri ve süreçleri kabul etme ve destekleme eğilimi olarak tanımlamışlardır. Benzer şekilde Hughes ve Morgan'da (2007) yenilikçiliği, müşterilerin taleplerini en iyi şekilde karşılayacak yeni çözümler üretmek adına, ürünlerin, hizmetlerin ve süreçlerin geliştirilmesinde yaratıcılığı, deneyleri, teknolojik liderliği ve araştırma geliştirme faaliyetlerini benimseme ve desteklemeye yönelik ön yargı olarak tanımlamışlardır. Yoğun rekabetin ve 
T Girişimcilik Yönelimi İle Finansal Performans Arasındaki İlişkide Araştırma ve Geliştirme (AR-GE) Kapasitesinin Aracı Rolü Üzerine Bir Araştırma: Istanbul ve Kocaeli Bölgesi Örneği

hızlı değişimin yaşandığı günümüz ekonomilerinde yenilikçiliğin işletmeler için çok önemli ve kritik bir kavram olduğu ileri sürülmektedir. Bu nedenle yenilikçilik işletmelerin rakipleri karşısında rekabet avantajı yaratarak bu avantajın sürdürülmesi için bir araç olarak tanımlanmaktadır (Sanding ve Kiniti, 2011: 289; Gürkan ve Gürkan, 2017: 214). İşletme yöneticilerinin yenilik yapabilme yeteneklerinin işletmenin finansal performansının önemli bir parçası olduğu literatürde kabul gören bir görüştür. $\mathrm{Bu}$ doğrultuda işletmelerin yenilikçilik kapasiteleri ile finansal performansları arasında doğrusal bir ilişki olduğu öne sürülebilir (Gürkan ve Gürkan, 2017:213).

\subsubsection{Proaktiflik}

Proaktiflik, yoğun rekabet ortamında rakip firmaların önünde yeni ürün veya hizmetlerin sunulması özelliğini ortaya koyarak, gelecekteki talep tahminleriyle hareket eden ileriye dönük bir perspektiftir (Rauch vd., 2009: 7). Schillo (2011) proaktifliği, ürün, teknoloji, piyasa ve tüketici talepleri açısından firsatları öngörmek için girişimci eylemlerinin karakteristik özelliği olarak tanımlar. Proaktif firmaların amacı, kısa vadede piyasada ilk kullanıcı olarak var olup bu ilk olmanın avantajlarından yararlanmak, uzun vadede ise pazarın yönünü şekillendirebilmektir (Hughes ve Morgan, 2007: 653). Firmalar rakipleri karşısında üstünlükler elde edip bu üstünlüğü devam ettirebilmeleri için proaktif olmak durumundadırlar (Akman ve Yilmaz, 2008: 90). Proaktif firmalar piyasadaki avantajları yakalamak ve bu durumu devam ettirebilmek için yenilikleri kullanırlar (Ozsomer vd., 1997: 411). Bunun için firmaların proaktif tutum ve davranışları yeniliğin temel bileşenlerinden biridir (Morgan ve Strong, 1998: 1057).

\subsubsection{Risk Alma}

Fransız Cantillon girişimcilik kavramını ilk kez geliştirdiği dönemlerde girişimciyi kar ve zarar riskine katlanan kişi olarak tanımladığ 1 günden bugüne risk alma kavramı girişimciliğin temel boyutlarından biri olarak değerlendirilmektedir (Lumpkin ve Dess, 1996; Ağca ve Kurt, 2007). Risk, kaybetme olasıllı̆̆ anlamına gelen bir kavram olup, işletmelerin yenilikçi tutum ve davranışlarının, yeni girişimler başlatma eğiliminde olmalarının ve proaktiflik eyleminin ayrılmaz parçalarından biri olarak kabul edilmektedir (Ağca ve Kurt, 2007: 94). Girişimcilik yönelimi prokatif olmayı ve makul seviyelerde de risk almayı gerekli kılan bir kavramdır (Altuntaş ve Dönmez, 2010: 55). Çünkü günümüzde yoğun bir şekilde yaşanan rekabet ve hızla değişen çevresel unsurlar karşısında işletmelerin değişen ve gelişen bu çevresel unsurlara hızlı bir şekilde adapte olarak özellikle orta ve uzun vadede rakipleri karşısında teknik üstünlük sağlaması proaktif ve makul düzeyde risk alma kabiliyetine bağlıdır. Risk almaktan kaçınan veya risk alama konusunda tutucu davranan işletmelerin yoğun piyasa koşullarında tutunmaları imkansız hale gelebilmektedir. $\mathrm{Bu}$ nedenle işletme yönetimleri iş görenlerini risk alma 
konusunda cesaretlendirici ve teşvik edici faaliyetlere ağırlık vermeleri gerekmektedir.

\subsection{Araştırma Geliştirme (AR-GE)}

İşletmeler açısından AR-GE, yeni bir ürün üreterek bu ürünün piyasada ticari bir kimliğe kavuşmasını sağlamak ve böylece satışların artmasını ve dolayısıyla karı artırarak işletmelerin özellikle uzun vadede varlıklarını devam ettirebilmeleri açısından önemli bir unsurdur (Işık vd. 2016: 28). İşletmelerin yeni ürünler ve/veya hizmetler ortaya koyabilmelerinin ön koşulu kuşkusuz ARGE yatırımlarıdır. Çünkü AR-GE inovasyonun ön koşuludur. Özellikle rekabetin yoğun olarak yaşandığ 1 sektörlerde hayatını idame ettirmek durumunda olan işletmelerin rakipleri karşısında piyasada tutuna bilmeleri için yeni ürün ve/veya hizmetler ortaya koymaları bir zorunluluktur. Çünkü yenilikçi olmayan veya yenilikçilik karşısında tutucu olan işletmelerin yenilikçi olan rakipleri karşısında zorluklarla karşı karşıya kalabilmektedirler.

Günümüz ekonomileri bilim ve teknoloji temeline dayanmaktadır. Bu ekonomi anlayışta AR-GE, işletmelerin rakipleri karşısında rekabet üstünlüklerini ellerinde tutarak faaliyetlerini karlı bir şekilde sürdürebilmeleri açısından olmazsa olmaz bir koşul haline gelmiştir (Ünal ve Seçilmiş, 2013: 12). Yapılan teorik ve ampirik araştırmalar AR-GE harcamalarının özellikle uzun vadede firmaların performansı üzerinde etkili olduğu ve bu etkininde pozitif yönde olduğu belirtilmektedir (Doğan ve Yıldız, 2016: 179). Bu doğrultuda işletmeler stratejik planlarının odak noktasına yeniliği oturtmalidırlar.

\subsection{Finansal Performans}

Performans kavramı, amaçlı veya planlanmış bir etkinliğin sonucunda elde edilenin nicel veya nitel olarak ifade edilmesi olarak adlandırılmaktadır. İşletmeler açısından performans ise işletmenin belirli bir zaman dilimi sonucunda elde ettiği çıktı veya çalışma sonuçlarıdır (Öncü vd., 2015: 150). Başka bir ifadeyle finansal performans, finansal performans değerlendirme kriterleri dikkate alınarak işletmelerin belirli bir dönemdeki amaçlarına ne ölçüde ulaştıklarının değerlendirilmesidir (Bulut vd., 2009: 517). Gürkan ve Gürkan (2017)'da finansal performansı, bir örgütün sahip olduğu varlıklarını ne düzeyde etkili kullandığının ve ne kadar gelir yaratabildiğinin ölçüsü olarak tanımlamışlardır. Carton (2004)'da finansal, bir örgütün mali durumunda meydana gelen değişimin ya da yönetimin almış olduğu kararlardan ve alınan bu kararların uygulanmaya konulmasından kaynaklanan finansal sonuçların bir ölçüsü olarak tanımlamıştır. İşletmeler performanslarını ölçerek belirlemiş oldukları hedeflere ulaşıp ulaşamadıklarını belirleyebilirler. Aynı şekilde işletmelerin güçlü ve zayıf yönlerini ortaya koyarak geleceğe yönelik hedeflerini ona göre belirleme firsatı bulabilirler (Öncü vd., 2015: 150). Literatürde finansal performans ölçüsü olarak en çok kullanılan değişkenlerin, 
T Girişimcilik Yönelimi İle Finansal Performans Arasindaki İlişkide Araştırma ve Gelişstirme (AR-GE) Kapasitesinin Aracı Rolü Üzerine Bir Araştırma: Ístanbul ve Kocaeli Bölgesi Örneği

aktif karlılığı (ROA), öz sermaye karlılığı (ROE), Pazar payı büyüklüğü, ciro karlılı̆̆1, yatırım karlılığı, ekonomik karlılık ve gelirlerin artış1 olduğu görülmektedir (Resmi vd. 2018; Lakhwani vd.; 2017; Kamatra ve Kartikaningdyah; 2015; Öncü vd.; 2015). Çalışmada da finansal performans göstergesi olarak, yatırım karlılığı, ekonomik karlılık, satış karlılığı ve öz sermaye karlılığı değişkenleri kullanılmıştır.

\section{Literatür Taraması}

Literatürde girişimcilik yöneliminin finansal performans üzerindeki etkisini araştıran çok sayıda ulusal ve uluslararası ampirik çalışma mevcuttur. $\mathrm{Bu}$ çalışmalardan önemli sonuçlar ortaya koyanların bazıları aşağıda özetlenmiştir.

Şanal ve Girenay (2019) çalışmalarında, Adana ilinde faaliyet gösteren dört ve üstü yıldıza sahip otellerde çalışan 157 personelden anket yöntemi ile elde etmiş oldukları verileri kullanarak otellerde çalışanların risk alma ve proaktiflik boyutlarının finansal performans düzeyi arasındaki ilişkisini korelasyon analizi yöntemi ile incelemişlerdir. Çalışmalarının sonucunda, girişimcilik yönelimi boyutlarından risk alma ve proaktflik boyutları ile işletme performansı arasında istatistiki olarak anlamlı ilişki olduğunu tespit etmişlerdir. Okangi (2019) çalışmasında, 132 Tanzanya inşaat firması için, girişimcilik yöneliminin firma karlılı̆g üzerindeki etkisini çoklu regresyon analizi yöntemi ile incelemiştir. Çalışma sonuçları, girişimcilik yönelimi boyutlarından yenilikçilik ve risk almanın firma karlılığı üzerinde önemli derecede olumlu bir etkiye sahip olduğunu, proaktivite boyutunun ise, olumsuz yönde önemli bir etkisi olduğunu ortaya koymuştur. Basco vd. (2019) çalışmalarında; Çin, Meksika ve İspanya'da faaliyet gösteren 330 KOBİ için, girişimcilik yöneliminin firma performansı üzerindeki etkisini yapısal eşitlik modeli yöntemiyle incelemişlerdir. Çalışmalarının sonucunda, girişimcilik yöneliminin firma performansı üzerindeki etkisinin olumlu olduğunu tespit etmişlerdir. Cagle ve Özen (2019) çalışmalarında, 2018 yılı itibariyle BİST'e kayıtlı imalat sektöründe faaliyet gösteren 94 şirket için girişimcilik yönelimi ve finansal performans arasındaki ilişkide aile şirketlerinin moderatör etkisini çoklu regresyon yöntemiyle incelemişlerdir. Çalışmalarının sonucunda, girişimcilik yönelimi yüksek olan şirketlerin risk almaktan kaçındığı veya daha temkinli kararlar aldığını tespit etmişlerdir.

Mukarutesi (2018) çalışmasında, Ruanda'da faaliyet gösteren 226 KOBİ için girişimcilik yönelimi ile firma performansı arasındaki ilişkiyi regresyon analizi ile incelemiş̧ir. Çalışmanın sonucunda, girişimcilik yöneliminin hem KOBİ performansı hem de hükümet politikası ile önemli ve olumlu bir şekilde ilişkili olduğunu tespit etmiştir. Jiang vd. (2018) çalışmalarında, Çinin "Guangdong, Jiangsu, Shandong, Shaanxi ve Henan" beş farklı bölgesinde faaliyet gösteren 264 firma için yeşil girişimcilik yöneliminin finansal performans üzerindeki etkisini regresyon analizi ile incelemişlerdir. 
Çalışmalarının sonucunda, yeşil girişimcilik yöneliminin finansal performans üzerindeki etkisinin olduğunu tespit etmişlerdir. Pilatin ve Ergun (2017) çalışmalarında, Ankara ve Bursa illerinde faaliyet gösteren 163 KOBİ üretim işletmeleri için girişimcilik yönelimi ile ihracat ve satış büyüme performansı (firma performansı) arasındaki ilişkiyi çoklu ve hiyerarşik regresyon analizi ile incelemişlerdir. Çalışmalarının sonucunda, girișimcilik yönelimi ile ihracat ve satış büyüme performansı (firma performans1) arasında pozitif ve anlamlı bir ilişki olduğunu tespit etmişlerdir. Aminu (2016) çalışmasında, Nijerya'ya bağlı Kano Eyalet bölgesinde faaliyet gösteren ve rastgele seçilen 125 KOBİ için, girişimcilik yöneliminin finansal performans üzerindeki etkisini yapısal eşitlik modeli yöntemiyle incelemiştir. Çalışma sonucunda, girişimcilik yönelimi boyutlarından yenilikçilik, proaktiflik ve risk almanın finansal performans üzerindeki etkisinin önemli ve pozitif yönde olduğunu tespit etmiştir. Papatya vd. (2016) çalışmalarında, İSO-500 listesinde yer alan 51 tekstil işletmesi için, girişimcilik yönelimi ve iç girişimcilik ile finansal performans arasındaki ilişkiyi yapısal eşitlik modeli ile incelemişlerdir. Çalışmalarının sonucunda, girişimcilik yönelimi ile finansal performans arasındaki ilişkide pozitif yönlü bir ilişki olduğu hipotezini reddettiğini tespit etmişlerdir.

Kurtulmuş ve Warner (2015) çalışmalarında, İstanbul'da değişik sektörlerde faaliyet gösteren $117 \mathrm{KOBİ} \mathrm{için} \mathrm{girişimcilik} \mathrm{yönelimi} \mathrm{ve} \mathrm{algılanan}$ finansal performans arasındaki ilişkiyi regresyon analizi yöntemi ile incelemişlerdir. Çalışmalarının sonucunda, girişimcilik yönelimi ile algılanan finansal performans arasında görünür ve anlamlı bir ilişki olmadığını tespit etmişlerdir. Petrović vd. (2015) çalışmalarında Sırbistan inşaat sektöründe faaliyet gösteren 180 firma için girişimcilik yönelimi ile firma performansı arasındaki ilişkide ulusal kültürün moderatör etkisini hiyerarşik doğrusal regresyon modeli ile incelemişlerdir. Çalışmalarının sonucunda; girişimcilik yönelimi ile firma performansı arasında doğrudan anlamlı bir ilişki olmadığını tespit etmişlerdir. Ngoze ve Bwisa (2014) çalışmalarında, Kenya'da faaliyet gösteren 200 imalat firması için, girişimcilik yöneliminin finansal performans üzerindeki etkisini çok değişkenli regresyon analizi yöntemiyle incelemişlerdir. Çalışmalarının sonucunda, girişimcilik yönelimi boyutlarından, yenilikçilik, risk alma, rekabetçi saldırganlık ve özerkliğin finansal performans üzerinde olumlu ve önemli etkisinin olduğunu, proaktivitenin ise olumsuz ve önemli olmayan bir etkisi olduğunu tespit etmişlerdir. Altuntaş ve Dönmez (2010) çalışmalarında; Çanakkale çevresinde bulunan otel işletmelerinde, girişimcilik yöneliminin örgütsel performans üzerindeki etkisini, çoklu doğrusal regresyon analiz yöntemleriyle incelemişlerdir. Çalışmalarının sonucunda, girişimcilik yönelimi boyutlarından yenilikçilik, proaktiflik ve saldırgan rekabetçiliğin finansal performans üzerindeki etkisinin pozitif yönde olduğunu tespit etmişlerdir.

Aynı şekilde literatürde AR-GE harcamaları/yatırımlarının finansal performans üzerindeki etkisini araştıran çok sayıda ulusal ve uluslararası 
T Girişimcilik Yönelimi İle Finansal Performans Arasındaki İlişkide Araştırma ve Geliştirme (AR-GE) Kapasitesinin Aracı Rolü Üzerine Bir Araştırma: Istanbul ve Kocaeli Bölgesi Örneği

ampirik çalışma mevcuttur. Bu çalışmalardan önemli sonuçlar ortaya koyanların bazıları aşağıda özetlenmiştir.

Kılıç (2020) çalışmasında, BİST bilişim endeksinde işlem gören 7 firmanın 2012-2018 yılları arasındaki verilerinden yararlanarak, AR-GE harcamalarının firmaların finansal performansı üzerindeki etkisini panel veri analizi ile incelemiş̧ir. Çalışma sonucunda, AR-GE yoğunluğu oranının finansal performans göstergeleri üzerindeki etkisinin istatistiksel olarak anlamlı ve pozitif yönlü olduğunu tespit etmiştir. Demir ve Güleç (2019) çalışmalarında, BİST'e kayıtlı 60 imalat işletmesinin 2005-2016 yılları arasındaki verilerini kullanarak AR-GE harcamalarının firma karlılığ üzerindeki etkisini panel veri analizi yöntemiyle incelemişlerdir. Çalışmalarının sonucunda, AR-GE harcamalarının firma karlılı̆̆ üzerindeki etkisinin istatistiki olarak anlamlı ve pozitif yönlü olduğunu tespit etmişlerdir. Aytekin ve Özçalık (2018) çalışmalarında, BİST teknoloji ve bilişim endekslerinde işlem göre 7 işletmenin 2011-2018 yılları arasındaki verilerinden yararlanarak, AR-GE ve finansal performans arasındaki ilişkiyi panel veri analizi ile incelemişlerdir. Çalışmalarında bağımlı değişkenler olarak, FVÖK, ROIC ve Net Satışlar; bağımsız değişkenler olarak ta AR-GE Harcamaları, AR-GE/Net Satışlar, ARGE/Toplam Faaliyet Giderleri ve Piyasa Değeri/Defter Değerlerini kullanmışlardır. Çalışmalarının sonucunda, FVÖK'ün bağımlı değişken olduğu birinci modelde FVÖK ile AR-GE Harcamaları ve Piyasa Değeri/Defter Değeri arasında pozitif, AR-GE/Toplam Faaliyet Giderleri arasında ise negatif anlamlı ilişki olduğunu tespit etmişlerdir. Net Satışların bağımlı değişken olduğu modelde, Net Satışlar ile AR-GE Harcamaları arasında pozitif, AR-GE/Toplam Faaliyet Giderleri arasında ise negatif anlamlı ilişki olduğunu, ROIC bağımlı değişkeni ile de istatistiki olarak anlamlı bir ilişki olmadığını tespit etmişlerdir. Ayaydın vd. (2018) çalışmalarında, BRICS-TM ülkeleri (Brezilya, Rusya, Hindistan, Çin, Güney Afrika, Türkiye ve Meksika) için 2000-2015 yılları arasındaki verilerden yararlanarak, AR-GE ve inovasyon yatırımlarının finansal gelişme üzerine etkilerini panel veri analizi ile incelemişlerdir. Çalışmalarının sonucunda, AR-GE ve inovasyon yatırımlarının finansal gelişme üzerinde pozitif etkisi olduğunu, AR-GE yatırımlarından finansal gelişmeye doğru tek yönlü nedensellik ilişkisi olduğunu tespit etmişlerdir.

Freihat ve Kanakriyah (2017) çalışmalarında, Amman borsasına kayıtlı 6 Ürdün ilaç firmasının 2006-2015 yılları için AR-GE harcamalarının firma performansı üzerindeki etkisini basit doğrusal regresyon analizi yöntemi ile incelemişlerdir. Çalışmalarının sonucunda, AR-GE harcamalarının firma performansı üzerinde önemli bir etkisi olduğunu tespit etmişlerdir. Kıracı vd. (2016) çalışmalarında, BİST’e işlem gören 46 imalat firmasının 1998-2012 yılları arasındaki verilerini kullanarak AR-GE harcamalarının kısa ve uzun vadede karlılık üzerindeki etkisini panel veri analizi yöntemi ile incelemişlerdir. Çalışmalarının sonucunda, AR-GE harcamalarının kısa vadede karlılık üzerinde 
anlamlı bir etkisi olmamasına rağmen uzun vadede karlılık üzerinde önemli ve olumlu yönde etkisi olduğunu tespit etmişlerdir. Xu ve Jin (2016) çalışmalarında Çin'de Şangay ve Shenzhen borsasında kayıtlı 30 internet endüstri işletmesinin 2001-2013 yılları arasındaki verilerini kullanarak AR-GE yatırımlarının firma performansı üzerindeki etkisini çoklu doğrusal regresyon yöntemi ile incelemişlerdir. Çalışmalarının sonucunda, ilk olarak, AR-GE yatırımlarının mevcut firma performansı üzerinde önemli bir etkisi olmadığını, ikincisi AR-GE yatırımının ilk gecikme aşamasında kar marjı üzerinde olumlu bir etkisi olduğunu ve üçüncü olarak da AR-GE yatırımlarının kümülatif etkisinin firma performansı ile negatif korelasyonu olduğunu tespit etmişlerdir. Bouaziz (2016) çalışmasında, BİST teknoloji sektöründe faaliyet gösteren 12 şirketin 2010-2014 yılları için AR-GE'nin firma performansı üzerindeki etkisini havuzlanmış regresyon modeli ve kesitsel zaman serileri analiz yöntemi ile incelemiştir. Çalışma sonucunda, AR-GE'nin firma performansı üzerinde etkisinin olmadığını tespit etmiştir. Doğan ve Yıldız (2016) çalışmalarında, BİST'te işlem gören 136 firmanın 2008-2014 yılları arasındaki verilerinden yararlanarak, AR-GE harcamalarının firma karlılığı üzerindeki etkisini regresyon ve t-testi yöntemleri ile incelemişlerdir. Çalışmalarının sonucunda, AR-GE harcamalarında meydana gelen bir artışının firma karlılığını artırdığını tespit etmişlerdir.

Öztürk ve Zeren (2015) çalışmalarında, Türkiye'de faaliyet gösteren 26 imalat firmasının 2007-2014 yılları için AR-GE harcamalarının firma performansı üzerindeki etkisini panel veri analizi yöntemi ile incelemişlerdir. Çalışmalarının sonucunda, AR-GE harcamalarının firmaların satış büyümeleri üzerindeki etkisinin pozitif yönde olduğunu tespit etmişlerdir. Ayaydın ve Karaaslan (2014) çalışmalarında, BİST'e kayıtlı 145 imalat işletmesinin 20082013 yılları için AR-GE yatırımlarının finansal performans üzerindeki etkisini GMM tahmincisi yöntemiyle incelemişlerdir. Çalışmalarının sonucunda, ARGE yatırımlarının finansal performans üzerinde pozitif yönlü bir etkisi olduğunu tespit etmişlerdir. García-Manjón ve Romero-Merino (2012) çalışmalarında, 754 Avrupa firmasının 2003-2007 dönemi için AR-GE harcamaları ile firma büyümesi arasındaki ilişkiyi Regresyon, Quantile Regresyon ve GMM yöntemleri ile incelemişlerdir. Çalışma sonuçları, AR-GE harcamalarının satış büyümesi üzerinde olumlu etkisi olduğunu ortaya koymuştur.

\section{Metodoloji}

\subsection{Araştırmanın Veri Toplama Yöntemi}

Çalışmanın örneklemini İstanbul ve Kocaeli bölgesinde faaliyet gösteren 50 ve üzeri çalışanı olan imalat işletmeleri oluşturmaktadır. Kasıtlı örneklem yönteminin kullanıldığı çalışmada en az AR-GE departman yöneticisi olmak koşuluyla her bir işletme yöneticisine 2018 Ağustos ve 2019 Haziran ayları arasında gerek yüz yüze, gerek telefonla gerekse mail aracılığıyla ulaşılarak anket forumları doldurtulmuştur. Veriler 2020 yılından önce toplandığ 
T Girişimcilik Yönelimi Ile Finansal Performans Arasındaki Ilişkide Araştırma ve Geliştirme (AR-GE) Kapasitesinin Aracı Rolü Üzerine Bir Araştırma: Istanbul ve Kocaeli Bölgesi Örneği

kurul izin belgesi gerekmemektedir. Araştırmanın evrenini oluşturan işletmelere ait bilgiler İstanbul ve Kocaeli sanayi odası ile Sanayi ve Teknoloji Bakanlığı AR-GE Teşvikleri Genel Müdürlüğünün Resmi Web sitesinden temin edilmiştir. Teknoloji Bakanlığı AR-GE Teşvikleri Genel Müdürlüğüne kayıtlı 50 ve üzeri çalışanı ile AR-GE merkezi olan işletme sayısı, İstanbul bölgesi için 179, Kocaeli bölgesi içinde 31 'dir. Örnekleme toplamda 210 işletme dahil edilmiş 194 tanesine ulaşılmış bunlardan 130 tanesinden geri dönüş alınmıştır. Geri dönüşü olan bu işletmelerin tamamı da araştırma kapsamına dahil edilmiştir. Toplanan örneklemin yeterlilik konusu değişkenlerin analizinde kullanılan istatistiksel analiz yöntemi bağlamında değerlendirilmiştir (Demir ve Okan, 2009: 65). Araştırma kapsamında yer alan değişkenlerin analizinde kullanılan PLS-SEM (Partial Least Squares Based Structural Equation Modeling) modeli küçük örneklem problemlerini yeniden örnekleme tabi tutarak bu problemi ortadan kaldırdığından (Doğan, 2019:018) dolayı $(\mathrm{n}=130)$ örneklem sayısı yeterli bir sayıdır.

Çalışmada veri toplama aracı olarak anket tekniği kullanılmıştır. Ankette katılımcılara AR-GE kapasitesi ve girişimcilik yönelimi ile ilgili yöneltilen sorulardan her biri için kendileri açısından en uygun olan yanıtı vermeleri istenmiştir. Anketin derecelendirilmesinde; 1:Kesinlikle Katılmıyorum, 2:Katılmiyorum, 3: Kismen kat1lyorum, 4: Kat1liyorum, 5:Kesinlikle katıllyorum şeklinde olan, beşli likert ölçeği kullanılmıştır. Finansal performans ölçeği ile ilgili derecelendirmede ise, 1:Son Derece Başarısız, 2:Başarısız, 3:Kısmen Başarılı, 4: Başarıl1, 5:Son Derece Başarılı şeklinde olan, beşli likert ölçek kullanılmıştır.

\subsection{Araştırmanın Analiz Yöntemi}

Araştırmanın amacı doğrultusunda literatüre paralel olarak geliştirilen hipotezlerin test edilmesinde, yapısal eşitlik modellerinden varyans tabanlı PLSSEM yaklaşımı kullanılmıştır. Bu yaklaşımın kullanılmasının temel nedeni örneklem sayısının az olmasıdır. Çünkü kovaryans bazlı CB-SEM yaklaşımı büyük örnekleme ihtiyaç duymaktadır. Diğer bir nedeni ise PLS-SEM yaklaşımının verilerin normal dağılım gösterip göstermediği konusunda CBSEM yaklaşımı kadar duyarlı olmaması.

\subsection{Araştırmanın Hipotezleri}

Araştırmanın amacı ve modeli kapsamında, teorik kuramın genel argümanları doğrultusunda literatüre paralel bir şekilde aşağıdaki hipotezler geliştirilebilir:

H1: Girişimcilik yönelimi direkt olarak finansal performans üzerinde etkili olacaktır.

H1a: Girişimcilik yönelimi boyutlarından yenilikçilik direkt olarak finansal performans üzerinde etkili olacaktır.

H1b: Girişimcilik yönelimi boyutlarından proaktiflik direkt olarak finansal performans üzerinde etkili olacaktır. 
H1c: Girişimcilik yönelimi boyutlarından risk alma direkt olarak finansal performans üzerinde etkili olacaktır.

H2: Girişimcilik yönelimi dolaylı olarak AR-GE kapasitesi üzerinden finansal performans üzerinde etkili olacaktır.

H2a: Girişimcilik yönelimi boyutlarından yenilikçilik dolaylı olarak ARGE kapasitesi üzerinden finansal performans üzerinde etkili olacaktır.

H2b: Girişimcilik yönelimi boyutlarından proaktiflik dolaylı olarak ARGE kapasitesi üzerinden finansal performans üzerinde etkili olacaktır.

H2c: Girişimcilik yönelimi boyutlarından risk alma dolaylı olarak ARGE kapasitesi üzerinden finansal performans üzerinde etkili olacaktır.

\subsection{Araştırmanın Modeli}

Teoriye göre, günümüz ekonomilerinde işletmelerin ulusal ve uluslararası piyasalarda varlıklarını devam ettirebilmeleri için yenilikçi olmaları vazgeçilmez bir durumdur. İşletmelerin yenilik yapabilme yeteneğinin onların performanslarının önemli bir parçası olduğu literatürde kabul gören bir görüştür (Gürkan ve Gürkan, 2017: 213). Yapılan birçok araştırma sonucu, yenilikçiliğin işletme performansı üzerinde etkili olduğunu ortaya koymuştur (Gürkan ve Gürkan, 2017; Doğan ve Doğan, 2017; Bockova ve Zizlavsky, 2016; Chua vd., 2016; Öztürk vd., 2013). İşletmelerin yenilikçi olmaları ise AR-GE faaliyetlerine bağlıdır. Çünkü AR-GE faaliyetleri yenilikçilik sürecinin ayrılmaz bir parçası ve ön koşuludur. Aynı şekilde girişimcilerin AR-GE harcamaları konusundaki tutum ve davranışları da işletmelerin finansal performanslarını etkilemektedir. Sonuç olarak AR-GE kapasitesi yüksek olan işletmelerin finansal performansları da yüksek olmaktadır. Değilse finansal performansları da düşük olmaktadır. Kısaca teoriye göre, girişimcilik yönelimi doğrudan ve/veya AR-GE kapasitesi üzerinden finansal performans üzerinde etkili olabilmektedir.

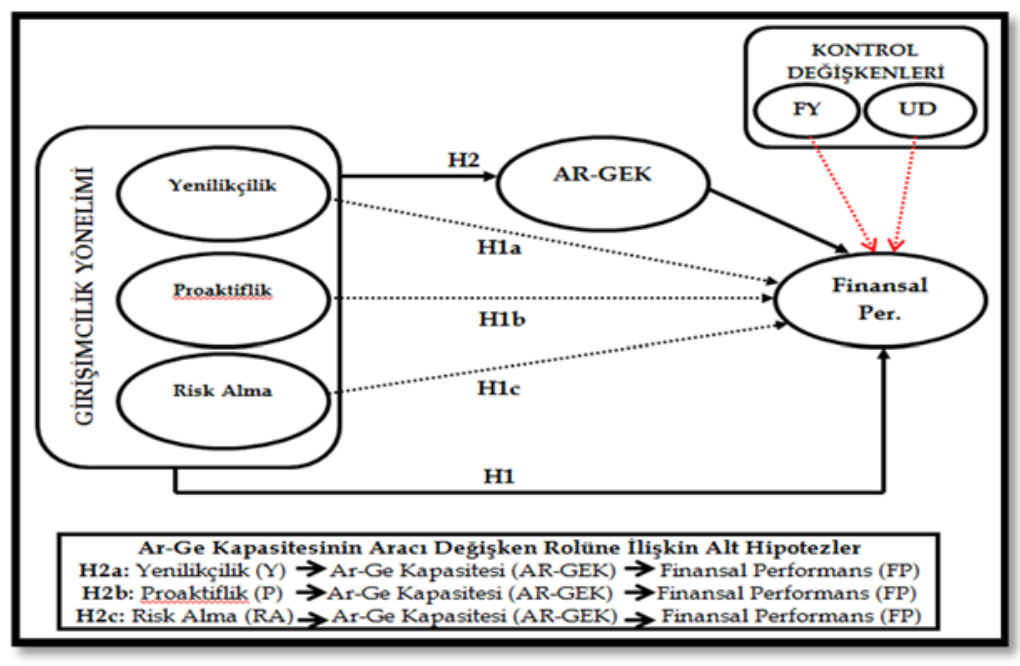


T Girişimcilik Yönelimi Ile Finansal Performans Arasındaki Ilişkide Araştırma ve Geliştirme (AR-GE) Kapasitesinin Aracı Rolü Üzerine Bir Araştırma: Istanbul ve Kocaeli Bölgesi Örneği

Şekil 1. Araştırmanın Modeli

Şekil 1'de görülen araştırma modeli, girişimcilik yöneliminin finansal performans üzerindeki etkisinde AR-GE kapasitesinin aracı rolünü test etmek için tasarlanmıştır. Bu tür ilişkilerin analizinde en çok kullanılan yöntem Baron ve Kenny (1986) yöntemidir. Baron ve Kenny (1986) yöntemine göre AR-GE kapasitesinin aracı değişken olabilmesi için üç koşulun sağlanması gerekmektedir. Bunlardan ilk adım, girişimcilik yönelimi ile finansal performans arasındaki ilişkinin istatistiki olarak anlamlı olması gerekmektedir. Ancak bu koşul son yıllarda bir çok araştırmacı (Preacher ve Hayes, 2008; Zhao vd., 2010; Hayes, 2013) tarafından eleştirilmekte ve zorunlu bir adım olarak görülmemektedir (Doğan, 2019: 104). İkinci adım, girişimcilik yönelimi ile AR-GE kapasitesi arasındaki ilişkinin istatistiki olarak anlamlı olması gerekmekte olup, bu ilişki sağlanmaktadır. Üçüncü adım ise AR-GE kapasitesi ile finansal performans arasındaki ilişkinin istatistiki olarak anlamlı olması gerekmekte olup bu ilişkide sağlanmaktadır. Bu durumda Baron ve Kenny (1986) yöntemine göre, birinci adım ki son dönemlerde araştırmacılar tarafından eleştirilmekte olan bu koşulu araştırma değişkenleri arasındaki ilişki sağlamamaktadır. Ancak araştırma değişkenleri arasındaki ilişki diğer iki koşulu sağladığından dolayı AR-GE kapasitesinin aracı değişken olabileceği söylenebilir.

\subsection{Araştırmanin Değişkenleri}

Araştırma kapsamında yer alan modele ilişkin değişkenlere ait bilgiler Tablo 1'de verilmiştir.

Tablo 1. Araştırma Kapsamındaki Değiş̧kelere Ait Bilgiler

\begin{tabular}{|c|c|c|}
\hline & Kodu & Değişken Türü \\
\hline GİRISSIMCILLIK YÖNELIMI & & Bağımsız Değişken \\
\hline Yenilikçilik & $\mathrm{Y}$ & Bağımsız Değişken \\
\hline Proaktiflik & $\mathrm{P}$ & Bağımsız Değişken \\
\hline Risk Alma & $\mathrm{R}$ & Bağımsız Değişken \\
\hline $\begin{array}{l}\text { ARAŞTIRMA GELİ̧STIRME } \\
\text { KAPASITESİ }\end{array}$ & AR-GEK & Aracı (Mediatör) Değişken \\
\hline FİNANSAL PERFORMANS & FP & Bağımlı Değişken \\
\hline Firma Yaşı & & Kontrol Değişken \\
\hline Uluslararas1 Deneyim & & Kontrol Değişken \\
\hline
\end{tabular}

\section{6. Örneklem ve Ölçeklerin Genel Özellikleri}

Tablo 2'de araştırma kapsamındaki işletmelerin, personel sayıları, ihracat ve ithalat gibi uluslararası deneyimleri, işletme yaşı, katılımcıların işletmedeki pozisyonları ve cinsiyetleri verilmiştir. Tablo 2 incelendiğinde, örneklemin yaklaşık \% 89'unu üretim işletmeleri oluşturduğu görülmektedir. Araştırmaya katılanların yaklaşık \%83'ü AR-GE departman müdürü, $\% 3,8$ 'i sahibi/ortağ 1 , $\% 6,2$ 'si $\mathrm{CEO} / \mathrm{COO}$ ve $\% 6,9$ 'u ise diğer yöneticilerden oluşmaktadır. $\mathrm{Bu}$ 
katılımcıların \% 30,8'i bayan, \% 69,2'si ise erkek yöneticidir. Katılımcı firmaların personel sayıları incelendiğinde yaklaşık yarısını $(\% 48,5) 251$ ve üzeri çalışanı olan büyük işletmeler oluşturmaktadır. Aynı şekilde katılımcı işletmelerin yaş ve uluslararası deneyimleri incelendiğinde ise, yarısından fazlasının (\% 60) 21 yıldan fazla ve 50 yıldan az faaliyet gösteren işletmeler olduğu, katılımcı işletmelerin yaklaşık \% 67'sinin ise uluslararası piyasalarda faaliyet gösterdiği görülmektedir.

Tablo 2. Katılımcilara Ait Genel Özellikler

\begin{tabular}{|c|c|c|c|c|c|c|c|}
\hline Değişken & Kategori & $\begin{array}{c}\text { Sıklık } \\
(n=130)\end{array}$ & $\%$ & Değișken & Kategori & $\begin{array}{c}\text { Siklık } \\
(n=130)\end{array}$ & $\%$ \\
\hline \multirow{2}{*}{ Cinsiyet } & Kadın & 40 & 30,8 & \multirow{5}{*}{$\begin{array}{l}\text { Çalışan } \\
\text { Sayısı }\end{array}$} & $50-100$ & 17 & 13,1 \\
\hline & Erkek & 90 & 69,2 & & $101-150$ & 21 & 16,2 \\
\hline \multirow{3}{*}{$\begin{array}{l}\text { Endüstri } \\
\text { Tipi }\end{array}$} & Üretim & 115 & 88,5 & & $151-200$ & 11 & 8,5 \\
\hline & Hizmet & 7 & 5,3 & & $201-250$ & 18 & 13,8 \\
\hline & $\begin{array}{l}\text { Toptan/Da } \\
\text { ğtım }\end{array}$ & 8 & 6,2 & & 251 ve üzeri & 63 & 48,5 \\
\hline \multirow{4}{*}{$\begin{array}{l}\text { İşletme } \\
\text { Pozisyon }\end{array}$} & $\begin{array}{l}\text { Sahibi/Ort } \\
\text { ağ1 }\end{array}$ & 5 & 3,8 & \multirow{6}{*}{$\begin{array}{l}\text { Uluslar } \\
\text { Arası } \\
\text { Deneyim }\end{array}$} & $1-5$ & 12 & 9,2 \\
\hline & $\begin{array}{l}\text { Başkan } \\
\text { (CEO/CO } \\
\mathrm{O})\end{array}$ & 8 & 6,2 & & $6-10$ & 19 & 14,6 \\
\hline & $\begin{array}{l}\text { Depart. } \\
\text { Müdürü }\end{array}$ & 108 & 83,1 & & $11-20$ & 43 & 33,1 \\
\hline & Diğer & 9 & 6,9 & & $21-50$ & 44 & 33,8 \\
\hline \multirow{4}{*}{$\begin{array}{l}\text { Firma } \\
\text { Yaşı }\end{array}$} & $6-10$ & 4 & 3,1 & & 51 ve üzeri & 12 & 9,2 \\
\hline & $11-20$ & 23 & 17,7 & & & & \\
\hline & $21-50$ & 78 & 60 & & & & \\
\hline & 51 ve üzeri & 25 & 19,2 & & & & \\
\hline
\end{tabular}

Tablo 3 incelendiğinde, her bir ölçeğin aritmetik ortalamasının 3 değeri üzerinde olduğu görülmektedir. $\mathrm{Bu}$ ölçeklerden yenilikçilik ölçeğindeki maddelerin aritmetik ortalamasının 4,03 olması örnekleme dahil olan işletmelerin yenilikçi olduklarını gösterir. Proaktiflik ölçeğindeki maddelerin aritmetik ortalamasının 3,54 olması örnekleme dahil olan işletmelerin çevrelerinde olup biten firsatları belirleyerek bu firsatları değerlendirip yeniliğe çevirdiklerini gösterir. Risk alma ölçeğindeki maddelerin aritmetik ortalamasının 3,34 olması örnekleme dahil olan işletmelerin risk alma konusunda çok fazla istekli olmadıklarını gösterir. AR-GE kapasitesi ölçeğine ilişkin maddelerin aritmetik ortalamasının 4,08 olması örnekleme dahil işletmelerin teknoloji düzeylerini ve yoğun bir şekilde AR-GE faaliyetlerini kullandıklarını gösterir. Bu ortalama aynı zamanda işletmelerin yüksek düzeyde ürün ve süreç teknolojilerini kullandığını da göstermektedir. Finansal performans ölçeğindeki maddelerin aritmetik ortalamasının 3,67 olması işletmelerin son üç yılda önceki yıllara göre pazar paylarını ve karlılıklarını artırdığını gösterir. 
$T$ Girişimcilik Yönelimi İle Finansal Performans Arasındaki İlişkide Araştırma ve Gelişstirme (AR-GE) Kapasitesinin Aracı Rolü Üzerine Bir Araştırma: Ístanbul ve Kocaeli Bölgesi Örneği

Tablo 3. Ölçeklerin Maddelerine Illişkin Ortalama ve Standart Sapmalar

\begin{tabular}{|c|c|c|c|}
\hline Ölçekler & Ortalama & Standart Sapma & Örneklem Sayıs \\
\hline Yenilikçilik & $4,03 *$ & $0,78^{* *}$ & 130 \\
\hline Y1 & 4,15 & 0,80 & \\
\hline Y2 & 3,93 & 0,72 & \\
\hline Y3 & 4,02 & 0,81 & \\
\hline Proaktiflik & $3,54 *$ & $1,00 * *$ & 130 \\
\hline P1 & 3,89 & 1,00 & \\
\hline $\mathrm{P} 2$ & 3,52 & 1,01 & \\
\hline $\mathrm{P} 3$ & 3,20 & 1,01 & \\
\hline Risk Alma & $3,34 *$ & $0,94 * *$ & 130 \\
\hline $\mathrm{R} 1$ & 3,32 & 0,96 & \\
\hline $\mathrm{R} 2$ & 3,32 & 0,93 & \\
\hline R3 & 3,38 & 0,93 & \\
\hline AR-GE Kapasitesi & $4,08 *$ & $0,83 * *$ & 130 \\
\hline ARGEK1 & 4,43 & 0,74 & \\
\hline ARGEK2 & 4,38 & 0,60 & \\
\hline ARGEK3 & 3,87 & 0,98 & \\
\hline ARGEK & 3,62 & 0,98 & \\
\hline Finansal Performans & $3,67 *$ & $0,70 * *$ & 130 \\
\hline FP1 & 3,74 & 0,72 & \\
\hline FP2 & 3,62 & 0,72 & \\
\hline FP3 & 3,69 & 0,68 & \\
\hline FP4 & 3,62 & 0,69 & \\
\hline
\end{tabular}

\section{Analiz ve Bulgular}

$\mathrm{Bu}$ bölümde, ölçeklere ilişkin güvenilirlik ve geçerlilik analizlerinin sonuçları açıklandıktan sonra, teorik kuramın temel argümanları doğrultusunda literatüre paralel bir şekilde geliştirilmiş olan hipotezlerin testi ve bu testlere ait sonuçlar açıklanacaktır.

\section{1. Ölçeklerin Güvenilirlik ve Geçerlilik Analizleri}

Çalışmanın devamı açısından güvenilirlik analizi yapılması gerekli olan bir analizdir. Çünkü güvenilirlik analizi, ölçülmek istenen her bir maddenin bir birleriyle olan tutarlılıklarını ve kullanılan ölçeğin problemi ne derece yansıttığını ifade eden bir analiz tekniğidir. Güvenilirlik analizi kapsamında, iç tutarlılık güvenilirliği için, Cronbach's Alpha değeri kullanılmıştır. Ancak Cronbach's Alpha değerinin ölçekte yer alan indikatör sayısından (Hartog vd. 1997: 24-25) ve ölçek içindeki boyutsallıktan (Akgül ve Çevik, 2005: 440; Demir ve Okan, 2008: 79) etkilenmesi nedeniyle eleştirilmektedir. Cronbach's Alpha değerindeki bu problemlerin ortadan kaldırılması için bileşik güvenilirlik (Composite Reliability/CR) değeri (Hair vd., 2014) ve rho_A değeri (Henseler vd., 2016) alternatif değer olarak sunulmaktadır. SmartPLS3 programı bu üç değeri de aynı anda hesaplaya bilme özelliğine sahip olduğundan bu üç değerde verilecektir. 
Literatürde ölçeğin kabul edilebilir olması için Cronbach Alfa $(\alpha)$ değerinin 0,70 'den büyük olması ifade edilmektedir (Nunnally, 1967). Aynı şekilde Henseler vd. (2016) tarafindan rho_A değerinin de 0,70'e eşit veya üzerinde olması gerektiği ifade edilmektedir. Bileşik güvenilirlik değeri içinde 0,70 ile 0,95 arasında bir değer alması ifade edilmektedir (Hair vd. 2014: 112; Sartestedt vd. 2017: 16). Tablo 4 incelendiğinde, Cronbach's Alpha değerinin 0,710 ile 0,912 arasında, rho_A değerinin 0,740 ile 0,967 arasında ve bileşik güvenilirlik değerinin ise 0,825 ile 0,938 arasında değer aldığı görülmektedir. $\mathrm{Bu}$ durum literatürde ifade edilen kritik eşik değerlerinden yüksek olduğu için değişkenlerin güvenilir olduğu söylenebilir.

Tablo 4. Güvenilirlik Analiz Sonuçları

\begin{tabular}{lccc}
\hline \multicolumn{1}{c}{ Değişken Adı } & $\begin{array}{c}\text { Cronbach's } \\
\text { Alpha }\end{array}$ & rho_A & Bileşik Güvenilirlik \\
\hline AR-GEK & 0,710 & 0,740 & 0,825 \\
Finansal Performans & 0,912 & 0,920 & 0,938 \\
Proaktiflik & 0,776 & 0,903 & 0,862 \\
Risk Alma & 0,871 & 0,967 & 0,916 \\
Yenilikçilik & 0,768 & 0,916 & 0,859 \\
\hline
\end{tabular}

Araştırma kapsamındaki değişkenlere ait ölçeklerin temel faktörlerini belirlemek ve ölçeğin yapı geçerliliğini test etmek için Fornell-Larcker analizi yapılmış ve analiz sonuçları Tablo 5'de verilmiştir.

Fornell-Larcker kriterine göre, araştırma kapsamındaki her bir değişkene ait AVE (Açılanan Ortalama Varyans) karekökünün, diğer değişkenlerle olan korelasyonundan büyük olması gerekmektedir (Doğan, 2019: 46). Bir başka ifadeyle koyu renkle gösterilen değerler ilgili değişkenin AVE değerinin karekökleri olup her bir değer bağlı olduğu sütundaki korelasyon değerlerinden yüksek olmak durumundadır. Bu doğrultuda Tablo 5 incelendiğinde, AR-GE kapasitesi değişkenin $(0,741)$, yenilikçilik değişkenin $(0,820)$, proaktiflik değişkenin $(0,827)$ ve risk alma değişkenin $(0,886)$ olduğu, bu değişkenlerin her biri bağlı olduğu sütundaki diğer değişkenlerin korelasyon değerlerinden daha yüksek olduğu görülmektedir. Bu durumda, araştırmanın modeline dahil bütün değişkenlere ait ölçeklerin geçerli olduğu söylenebilir.

Tablo 5. Fornell-Larcker Ayrı̧̧ma Geçerliliği ve Korelasyon Değerleri

\begin{tabular}{lccccc}
\hline \multicolumn{1}{c}{ Değişkenler } & ARGEK & FP & Proaktiflik & $\begin{array}{c}\text { Risk } \\
\text { Alma }\end{array}$ & Yenilikçilik \\
\hline ARGEK & 0,741 & & & & \\
FP & 0,358 & 0,890 & & & \\
Proaktiflik & 0,433 & 0,155 & 0,827 & & \\
Risk Alma & 0,147 & 0,106 & 0,488 & 0,886 & \\
Yenilikçilik & 0,424 & 0,106 & 0,456 & 0,369 & 0,820 \\
\hline
\end{tabular}


T Girişimcilik Yönelimi Ile Finansal Performans Arasındaki Ilişkide Araştırma ve Geliştirme (AR-GE) Kapasitesinin Aracı Rolü Üzerine Bir Araştırma: Istanbul ve Kocaeli Bölgesi Örneği

\subsection{Hipotezlerin Testi}

Tablo 6'da araştırmanın hipotezleri başlığı kısmında geliştirilen hipotezler ve bu hipotezlere dayanılarak geliştirilmiş olan modellerin test edilmesine yönelik sonuçlar verilmektedir. Bu sonuçlara göre, hem araştırma geliştirme kapasitesinin hem de uluslararası deneyimin direkt olarak finansal performans üzerinde etkili olduğu tespit edilmiştir. AR-GE kapasitesi finansal performans üzerinde istatistiki olarak anlamlı $(p=0,000)$ ve pozitif $(\beta=0,389)$ yönlü bir etkiye sahiptir. Bu durum AR-GE kapasitesindeki bir artış finansal performans üzerinde yaklaşık 0,39 birimlik bir artışa neden olmaktadır. Bir başka ifadeyle, AR-GE kapasitesi ve finansal performans arasında doğrusal bir ilişki olduğu gözlemlenmektedir. $\mathrm{Bu}$ durum $\mathrm{H} 3$ temel hipotezini desteklemektedir. Girişimcilik yönelimi boyutlarından yenilikçilik boyutunun finansal performans üzerindeki etkisinin anlamlı $(\mathrm{p}=0,282)$ olmadığ 1 tespit edilmiştir. $\mathrm{Bu}$ durumda $\mathrm{H} 1 \mathrm{a}$ alt hipotezi desteklenmemiştir. Girişimcilik yönelimi boyutlarından proaktiflik $(\beta=-0,052, p=0,603)$ ve risk alma $(\beta=0,107$, $\mathrm{p}=0,306$ ) boyutları ile finansal performans arasında da anlamlı bir ilişki tespit edilememiştir. $\mathrm{Bu}$ durumda $\mathrm{H} 1 \mathrm{~b}$ ve $\mathrm{H} 1 \mathrm{c}$ alt hipotezleri de desteklenmemiştir. Sonuç olarak girișimcilik yönelimi boyutlarının üçünün de finansal performans üzerinde anlamlı bir etkisinin olmaması girişimcilik yöneliminin finansal performans üzerinde direkt etkisinin olmadığını göstermektedir ve bu durumda H1 temel hipotezi reddedilmiştir. Ayrıca kontrol değişkenlerden biri olan uluslararasi deneyim (ihracat ve ithalat gibi) ile finansal performans arasinda $(\mathrm{p}=0,002)$ istatistiki olarak anlamlı bir ilişki tespit edilmiştir. Uluslararası deneyimde meydana gelen bir artış finansal performans üzerinde 0,33 birimlik bir artışa neden olmaktadır. Bir başka ifadeyle uluslararası deneyim ile finansal performans arasında doğrusal bir ilişki olduğu söylenebilir.

Tablo 6. Ölçüm Modeline Ait Yol Katsayıları T-İstatistik Değerleri

\begin{tabular}{lccccc}
\hline & $\begin{array}{c}\text { Orijinal } \\
\text { Orneklem } \\
\text { (OÖ) }\end{array}$ & $\begin{array}{c}\text { Örneklem } \\
\text { Ortalama } \\
\text { (ÖO) }\end{array}$ & $\begin{array}{c}\text { Standart } \\
\text { Sapma } \\
\text { (SS) }\end{array}$ & $\begin{array}{c}\text { T İstatistik } \\
(|\mathbf{O O ̈ / S S}|)\end{array}$ & $\begin{array}{c}\mathbf{P} \\
\text { Değeri }\end{array}$ \\
\hline ARGEK -> FP & 0,389 & 0,392 & 0,089 & 4,384 & $\mathbf{0 , 0 0 0 *}$ \\
Firma Yaşı -> FP & $-0,071$ & $-0,075$ & 0,089 & 0,802 & 0,423 \\
Proaktiflik -> ARGEK & 0,361 & 0,352 & 0,086 & 4,202 & $\mathbf{0 , 0 0 0 *}$ \\
Proaktiflik -> FP & $-0,052$ & $-0,051$ & 0,101 & 0,520 & 0,603 \\
Risk Alma -> ARGEK & $-0,144$ & $-0,129$ & 0,083 & 1,748 & 0,081 \\
Risk Alma -> FP & 0,107 & 0,111 & 0,105 & 1,024 & 0,306 \\
Uluslararası Den.-> FP & 0,332 & 0,333 & 0,106 & 3,147 & $\mathbf{0 , 0 0 2 *}$ \\
Yenilikçilik-> ARGEK & 0,313 & 0,322 & 0,084 & 3,730 & $\mathbf{0 , 0 0 0 *}$ \\
Yenilikçilik -> FP & $-0,092$ & $-0,101$ & 0,086 & 1,076 & 0,282 \\
\hline Not: $\left({ }^{*}\right) \%$ 1
\end{tabular}

Not: $\left(^{*}\right) \% 1$ önem düzeyinde anlamlı olduğunu göstermektedir. 
Tablo 7 incelendiğinde, girişimcilik yönelimi boyutlarından proaktiflik $(\mathrm{p}=0,002)$ ve yeniliğin $(\mathrm{p}=0,000)$ AR-GE kapasitesi üzerinden finansal performansı anlamlı ve pozitif yönde etkilediği görülmektedir. Ancak risk alma boyutunun $(\mathrm{p}=0,101)$ AR-GE kapasitesi üzerinden finansal performans üzerinde her hangi anlamlı bir etkisi olmadığı görülmektedir. Bu durumda üç girişimcilik alt boyutundan ikisinin (yenilikçilik ve proaktiflik) AR-GE kapasitesi üzerinden finansal performansı anlamlı ve pozitif yönde etkilemesi, girişimcilik yöneliminin AR-GE kapasitesi üzerinden dolaylı olarak finansal performans üzerinde anlamlı etkisi olduğunu göstermektedir. Başka bir ifadeyle girişimcilik yönelimi ile finansal performans arasında AR-GE kapasitesinin aracı rolü olduğu söylenebilir. $\mathrm{Bu}$ durumda $\mathrm{H} 2$ temel hipotezi ile $\mathrm{H} 2 \mathrm{a}$ ve $\mathrm{H} 2 \mathrm{~b}$ alt hipotezleri desteklenmiş ancak $\mathrm{H} 2 \mathrm{c}$ alt hipotezi reddedilmiştir.

Tablo 7. Ölçüm Modeline Ait Dolaylı Etki Yol Katsayıları T-İstatistik Değerleri

\begin{tabular}{lccccc}
\hline & $\begin{array}{c}\text { Orijinal } \\
\text { Örneklem } \\
(\mathrm{OÖ})\end{array}$ & $\begin{array}{c}\text { Örneklem } \\
\text { Ortalama } \\
(\mathrm{ÖO})\end{array}$ & $\begin{array}{c}\text { Standart } \\
\text { Sapma } \\
(\mathrm{SS})\end{array}$ & $\begin{array}{c}\text { T İstatistik } \\
(|\mathrm{OÖ} / \mathrm{SS}|)\end{array}$ & $\begin{array}{c}\mathrm{P} \\
\text { Değeri }\end{array}$ \\
\hline Proaktiflik ->AR-GE-> FP & 0,140 & 0,137 & 0,044 & 3,162 & $\mathbf{0 , 0 0 2 *}$ \\
Risk Alma ->AR-GE-> FP & $-0,056$ & $-0,050$ & 0,034 & 1,639 & 0,101 \\
Yenilikçilik ->AR-GE-> FP & 0,122 & 0,127 & 0,047 & 2,610 & $\mathbf{0 , 0 0 9 *}$ \\
\hline
\end{tabular}

Not: $(*) \% 1$ önem düzeyinde anlamlı olduğunu ifade etmektedir.

\section{Sonuç ve Öneriler}

Çalışmanın amacı, İstanbul ve Kocaeli bölgesinde faaliyet gösteren orta ve büyük ölçekli işletmeler açısından girişimcilik yöneliminin finansal performans üzerindeki etkisinde AR-GE kapasitesinin aracı rolünün olup olmadığını ampirik olarak incelemektir. Bu amaç doğrultusunda 130 firmadan anket yöntemiyle veriler elde edilmiştir. Elde edilen bu verilerin analizinde Yapısal Eşitlik Modeli (YEM) yaklaşımlarından varyans tabanlı PLS-SEM [(Partial Least Square (En Küçük Kareler-Yapısal Eşitlik Modellemesi)] yönteminden yararlanılmıştır.

Araştırmada ilk önce değişkenlere ait ölçeklerin güvenilirlik ve geçerlilik analizleri yapılmış, bu şart sağlandıktan sonra sırasıyla analiz ve bulgular ile doğrusallık testleri yapılmıştır. Araştırma sonuçları, AR-GE kapasitesi ile uluslararası deneyimin finansal performans üzerinde direkt etkili olduğunu ortaya koymuştur. Başka bir ifadeyle AR-GE kapasitesi ve uluslararası deneyimde meydana gelen bir artış finansal performans üzerinde de artışa neden olabilmektedir. Analiz sonuçları, (Demir ve Güleç, 2019; Freihat ve Kanakriyah, 2017; Kıracı vd., 2016; Öztürk ve Zeren, 2015; Ayaydın ve Karaaslan, 2014; García-Manjón ve Romero-Merino, 2012) yapmış oldukları Ar-Ge faaliyetleri ve/veya harcamalarının firma performansı üzerindeki etkileri konulu çalışmalarını destekler niteliktedir. 
T Girişimcilik Yönelimi İle Finansal Performans Arasındaki İlişkide Araştırma ve Geliştirme (AR-GE) Kapasitesinin Aracı Rolü Üzerine Bir Araştırma: Istanbul ve Kocaeli Bölgesi Örneği

Girişimcilik yönelimi ile girişimcilik yönelimi boyutlarından; proaktiflik, yenilikçilik ve risk almanın da finansal performans üzerinde direk etkisinin olmadığı tespit edilmiştir. Analiz sonuçları; (Papatya vd., 2016; Kurtulmuş ve Warner, 2015; Petrović vd., 2015) yapmış oldukları çalışmaları destekler niteliktedir. Girişimcilik yönelimi ve boyutlarının firma finansal performansı üzerinde direkt etkisinin olmamasının nedenleri olarak, Kemelgor'un (2002) da ifade ettiği gibi ülkelerin kültür ve girişimcilik yönünden farklı olmasıdır. Çünkü araştırma kapsamındaki girişimcilik yönelimi ile ilgili ölçek soruları, Li vd. (2017) tarafından yapılan çalışmanın ölçeği baz alınarak geliştirilmiştir. Bu durumda araştırma kapsamındaki firma yöneticilerinin yenilikçilik konusundaki düşünce ve görüşleri ile kültür yapılarının farklı olması, aynı sorulara farklı cevaplar verilmesine neden olmuş olabilir. Başka bir nedeni ise, 2018 Ağustos ayında yaşanan döviz krizi ile birlikte Türkiye ekonomisinde yaşanan daralma, başka bir ifadeyle stagflasyon riskinin firma yöneticilerinin yenilikçi, proaktif ve risk alma konusundaki tutum ve davranışlarını etkilemiş olduğu söylenebilir.

Girişimcilik yönelimi ile finansal performans arasında ise direkt bir etkinin olmadığı, ancak beklenildiği gibi bu etkinin AR-GE kapasitesi üzerinden olduğu tespit edilmiştir. Başka bir ifadeyle girişimcilik yönelimi ile finansal performans arasında AR-GE kapasitesinin aracı rolü olduğu söylenebilir. Bu durum işletme yöneticilerinin AR-GE ile ilgili stratejik planlar yapmalarını ve bu planların merkezine de yeniliği oturtmaları gerektiğini göstermektedir. Aynı şekilde politika yapıcıların da AR-GE teşvikleri konusuna daha fazla önem vermeleri gerektiğini göstermektedir. Çünkü AR-GE faaliyetleri sonucu ortaya çıkan yeni ürün ve hizmetler; üretimin ve ihracatın artmasına, ithalatın ise azalmasına neden olacağından dolayı, özellikle gelişmekte olan Türkiye için en büyük handikaplardan biri olan dış ticaret açığı ve cari açığı önemli ölçüde azaltacak ve döviz rezervlerinde artışa neden olacaktır.

Araştırma kapsamındaki işletme yöneticilerinin anketleri doldurma konusundaki isteksizlikleri ile finansal konulardaki finansal performans kriterleri ile ilgili firmalara ait oransal verilerin temin edilmesindeki zorluklar çalışmanın en önemli kısıtlarını oluşturmaktadır. Bu çalışmanın gelecekteki çalışmalara yol göstermesi açısından önemli olacağ araştırmacılara aşağıdaki öneriler verilebilir.

i. Araştırma sonuçlarının genellenebilmesi için çalışma farklı bölgelerde veya illerde yapılabilir.

ii. Araştırma orta ve büyük ölçekli işletme yöneticilerine uygulanmış olup, araştırma KOBİ'ler üzerinde yapılabilir.

iii. Araştırmanın evrensel olabilmesi için gelişim düzeyi farklı ülkeler ve/veya kıtalar karşılaştırılarak yapılabilir.

iv. Araştırmaya farklı değişkenlerde eklenerek daha kapsamlı değerlendirilebilir. 


\section{Kaynaklar}

Ağca, V. ve Kurt, M. (2007), "İç Girişimcilik ve Temel Belirleyicileri: Kavramsal Bir Çerçeve", Erciyes Üniversitesi İktisadi ve İdari Bilimler Fakülte Dergisi, 29, 83-112.

Akgül, A.ve Osman, Ç. (2005), İstatistik Analiz Teknikleri, Ankara: Emek Ofset.

Altuntaş, G. ve Dönmez, D. (2010), "Girişimcilik Yönelimi ve Örgütsel Performans İlişkisi: Çanakkale Bölgesinde Faaliyet Gösteren Otel İşletmelerinde Bir Araştırma”, İstanbul Üniversitesi İsletme Fakültesi Dergisi, 39(1), 50-74.

Aminu, M.İ. (2016), "Entrepreneurial Orientation and Financial Performance of Simple Firms in Nigeria", Sokoto Journal of Management Studies, 10(1), 1-15.

Ayaydın, H., Çam, A.V., Barut, A. ve Pala, F. (2018), “Araştırma Geliştirme ve İnovasyon Yatırımlarının Finansal Gelişme Üzerine Etkisi: BRICS-TM Ülkeleri Örneği”, Muhasebe ve Vergi Uygulamalar Dergisi, Özel Say1s, 442-461.

Ayaydın, H. ve Karaaslan, İ. (2014), “The Effect of Research and Development Investment on Firms' Financial Performance: Evidence from Manufacturing Firms in Turkey”, Bilgi Ekonomisi ve Yönetimi Dergisi, IX(II), 43-59.

Aygen, S. (2006), İşletmelerde Yenilik Yönetimi Sürecinde Örgüt Yapılarında ve Hizmet Tasarımlarında Yaşanan Dönüşümler: Antalya İli Beş Yıldızlı Konaklama İşletmelerinde Ampirik Bir Araştırma ve Hizmet Tasarımı Önerisi, Yayımlanmamış Doktora Tezi. Selçuk Üniversitesi Sosyal Bilimler Enstitüsü, Konya.

Aytekin, S. ve Özçalık, S.G. (2018), "Borsa İstanbul Teknoloji ve Bilişim Endeksi Firmalarında Ar-Ge Harcamaları ve Finansal Performans İlişkisi”, Anemon Muş Alparslan Üniversitesi Sosyal Bilimler Dergisi, 6(ICEESS' 18), 67-73.

Basco, R., Hernandez-Perlines, F. ve Rodriguez-Garcia, M. (2019), "The effect of entrepreneurial orientation on firm performance: A multigroup analysis comparing China, Mexico, and Spain", Journal of Business Research, 1-13.

Bockova, N., ve Zizlavsky, O.(2016), "Innovation and Financial Performance of A Company: A study From Czech Manufacturing Industry", Transformations in Business \& Economics, 15, 3(39), 156-175.

Bouaziz, Z. (2016), "The Impact of R\&D Expenses on Firm Performance: Empirical Witness from the Bist Technology Index", Journal of Business Theory and Practice, 4(1), 51-60.

Bruderl, J. ve Preisendorfer P. (2000), "Fast-Growing Businesses Empirical Evidence from a German Study", International Journal of Sociology, 30(3), 45-70. 
T Girişimcilik Yönelimi Ile Finansal Performans Arasındaki İlişkide Araştırma ve Geliştirme (AR-GE) Kapasitesinin Aracı Rolü Üzerine Bir Araştırma: Istanbul ve Kocaeli Bölgesi Örneği

Bulut, Ç., Yılmaz, C. ve Alpkan L. (2009), "Pazar Oryantasyonu Boyutlarının Firma Performansina Etkileri”, Ege Akademik Bakış/Ege Academic Review, 9(2), 513-538.

Cagle, M. ve Özen, A. (2019), "Girişimcilik Yönelimi ve Finansal Performans İlișkisinin Araştırılmasında Aile Şirketlerinin Moderatör Rolü”, Yönetim ve Ekonomi, 26(3), 879-902.

Carton, R.B. (2004), Measuring Organizational Performance: An Exploratory Study. A Dissertation Submitted to the Graduate Faculty of The University of Georgia in Partial Fulfillment of the Requirements for the Degree Doctor of Philosophy Athens, Georgia.

Chua, S.R., Chong, C.T., DY Ma. Catrina, S. ve Villavicencio, A.M.E. (2016). The Relationship of Corporate Financial Performance and Innovation among Manufacturing Industries, Presented at the DLSU Research Congress, March 7-9, Manila, Philippines.

Covin, J.G. ve Slevin, D.P. (1991), "A conceptual model of entrepreneurship as firm behavior", Entrepreneurship Theory and Practice, 16, 7-25.

Demir, C. ve Güleç, Ö. F. (2019), “Araştırma Ve Geliştirme Giderlerinin Firma Kârlılığı Üzerine Etkisi: Bist İmalat Sektörü Örneği”, Pamukkale Üniversitesi Sosyal Bilimler Enstitüsü Dergisi, 34, 57-72.

Demir, H. ve Okan, T. (2009), "Teknoloji, Örgüt Yapıs1 ve Performans Arasındaki İlişkiler Üzerine Bir Araştırma”, Doğuş Üniversitesi Dergisi, 10(1), 57-72.

Demir, H. ve Okan, T. (2008), "Etkileşimsel ve Dönüşümsel Liderlik: Bir Ölçek Geliştirme Denemesi”, Yönetim, 19(61), 72-90.

Doğan, Derya. (2019), SmartPLS ile Veri Analizi, 2.Baskl, Ankara: ZET Yayinları.

Doğan, H. ve Doğan, M.(2017), "Yenilikçilik ve Performans: Yüksek Teknoloji Kullanan Firmalar Üzerine Bir Araştırma", İnsan ve Toplum Bilimleri Araştırmaları Dergisi, 6(6), 153-62.

Doğan, M. ve Yıldız, F. (2016), "Araştırma ve Geliştirme Harcamalarının (ARGE) Firma Karlılığ Sanayi Firmaları Üzerine Bir Araştırma”, Kastamonu Üniversitesi Iktisadi ve İdari Bilimler Fakültesi Dergisi, 14, 178-187.

Fiş, A.M. ve Wasti, S. A. (2009), "Örgüt Kültürü ve Girişimcilik Yönelimi İlişkisi”, ODTÜ Gelişme Dergisi, 35 (Özel Sayı), 127-164.

Freiha, A.R.F. ve Kanakriyah, R. (2017), "Impact of R\&D Expenditure on Financial Performance: Jordanian Evidence", European Journal of Business and Management, 9(32), 73-83.

García-Manjón, V.J. ve Romero-Merino, M.E. (2012), "Research, Development, and Firm Growth. Empirical Evidence From European Top R\&D Spending Firms”, Research Policy, 41, 1084-1092. 
Gürkan, N. ve Gürkan, S. (2017), "Yenilikçilik Kavramının İşletmelerin Finansal Performansı Üzerindeki Etkisi", Uluslararası Yönetim İktisat ve İşletme Dergisi, ICMEB 17 Özel Sayısı, 213-226.

Hair, J.F., Hult, G.T.M., Ringle, C.M. ve Sarstedt, M. (2014), A Primer on Partial Least Squares Structural Equation Modeling (PLS-SEM). Second Edition, Los Angeles: Sage Publication.

Hartog, D.N.D, Muijen, J.J.V. ve Koooman P.L. (1997), "Transactional versus transformational leadership: An analysis of the ML", Journal of Occupational and Organizational Psychology, 70, 19-3.

Hensler, J., Hubona, G. ve Ray, P.A. (2016), "Using PLS path modeling in new technology research: updated guidelines" Industrial Management \& Data Systems, 116(1), 2-20.

Hughes, M. ve Morgan, R.E. (2007), "Deconstructing the relationship between entrepreneurial orientation and business performance at the embryonic stage of firm growth", Industrial Marketing Management, 36, 651-661.

Işık, N., Engeloğlu, Ö. ve Kılınç, E.C. (2016), "Araştırma ve Geliştirme Harcamalarının, Karlılık ve Satışlar Üzerindeki Etkisi: Borsa İstanbul Firmaları Üzerine Bir Uygulama" Erciyes Üniversitesi İktisadi ve İdari Bilimler Fakültesi Dergisi, 47, 27-46.

Jiang, W., Chai, H., Shao, J. ve Feng, T. (2018), "Green entrepreneurial orientation for enhancing firm performance: A dynamic capability perspective", Journal of Cleaner Production, 198, 1311-1323.

Kamatra, N. ve Kartikaningdyah, E. (2015), "Effect Corporate Social Responsibility on Financial Performance", International Journal of Economics and Financial Issues, 5(Special Issue), 157-164.

Kemelgor, B.H. (2002), "A comparative analysis of corporate entrepreneurial orientation between selected firms in the Netherlands and the USA", Entrepreneurship Regional Development, 14(1), 67-87.

Kılıç, M. (2020), BIST Bilişim Sektöründeki Firmaların AR-GE Harcamalarının Finansal Performans Üzerindeki Etkisi”, Erciyes Üniversitesi Sosyal Bilimler Enstitüsü Dergisi, XLIX, 2020/2, 219-234.

Kıracı, M., Çelikay, F. ve Çelikay, D. (2016), "The Effects of Firms' R \& D Expenditures on Profitability: An Analysis with Panel Error Correction Model for Turkey" International Journal of Business and Social Science, 7(5),233-240.

Kurtulmuş, B.E. ve Warner, B. (2015), "Entrepreneurial Orientation and Perceived Financial Performance. Does Environment Always Moderate EO Performance Relation", Procedia-Social and Behavioral Sciences, 207, 739-748.

Lakhwani, V.M., Tiwari S. ve Jauhari, S. (2017), “Mergers and Acquisitions's Impact on Financial Performance: An Evaluation with Perspective of Time", J Fundam Appl Sci., 9(5), 945-957. 
T Girişimcilik Yönelimi Ile Finansal Performans Arasındaki İlişkide Araştırma ve Geliştirme (AR-GE) Kapasitesinin Aracı Rolü Üzerine Bir Araştırma: Istanbul ve Kocaeli Bölgesi Örneği

Lumpkin, G.T. ve Dess, G.G. (2001), "Linking Two Dimensions of Entrepreneurial Orientation to Firm Performance: The Moderating Role of Environment and Industry Life Cycle", Journal of Business Venturing, 16 (5), 429-451.

Lumpkin, G.T. ve Dess, G.G. (1996), "Clarifying the entrepreneurial orientation construct and linking it to performance", Academy of Management. The Academy of Management Review, 21(1), 135-172.

Miller, D. (1983), "The Correlates of Entrepreneurship in Three Types of Firms", Management Science, 29(7), 770-791.

Mukarutesi, D. (2018), "The Relationship between entrepreneurial orientation, government policy and SME performance: The case of small and medium enterprises in Rwanda", East Africa Research Papers in Business, Entrepreneurship and Management, EARP-BEM No:10.

MÜSİAD. (2012), Küresel Rekabet Iç̧in $A R-G E$ ve İnovasyon, Stratejik Dönüşüm Önerisi. MÜSİAD Araştırma Raporlart: 76, İstanbul: Pelikan Basım.

Ngoze, M. ve Bwisa, H. (2014), "Entrepreneurial Orientation and Financial Performance of Manufacturing Firms in Developing Countries: are Kenya's Manufacturing Firms Exempted?" https://papers.ssrn.com/sol3/papers.cfm?abstract_id=2490713, (Erişim: 16.12.2019).

Nunnally, Y.J.C. (1967), Psychometric theory, New York, NY, US: McGrawHill.

Okangi, F.P. (2019), "The impacts of entrepreneurial orientation on the profitability growth of construction firms in Tanzania", Journal of Global Entrepreneurship Research, 9(14), 1-23.

Öncü, M.A., Bayat, M., Kethüda, Ö. ve Zengin, E. (2015), "Yenilik ve Müşteri Performansının Finansal Performans Üzerindeki Etkisi: Orta Ölçekli Sanayi İşletmelerinde Bir Araştırma", Marmara Üniversitesi İ.̇.B. Dergisi, XXXVII (I), 149-164.

Öztürk, E. ve Zeren, F. (2015), “The Impact of R\&D Expenditure on Firm Performance in Manufacturing Industry: Further Evidence From Turkey", International Journal of Economics and Research, 6, 32-36.

Öztürk, E., Mesci M. ve Kılınç, İ. (2013), "Yenilik Faaliyetlerinin İşletme Performansına Etkisi: Yat Limanları Üzerine Bir Değerlendirme", Girişimcilik ve Kalkınma Dergisi, 8(2), 97-118.

Papatya, G., Papatya, N. ve Hamşığlu, A.B. (2016), "Girişimci Yönlülük, İçGirişimcilik ce Finansal Performans İlişkisi: Türkiye Tekstil Sektörü İşletmelerinde Bir Araştırma”, Hacettepe Üniversitesi İktisadi ve İdari Bilimler Fakültesi Dergisi, 34(4), 19-48.

Petrovic, Z., Vukotic, S., Anicic, J. ve Zakic, N. (2015), "Moderating effect of national culture on the relationship between entrepreneurial orientation and business performance: An evidence from Serbia", (JPMNT) 
Journal of Process Management-New Technologies, International, 3(4), 84-89.

Platin, N. ve Ergün, H.S. (2017), "The Relationship between Entrepreneurial Orientation and Performance; Evidence from Turkish SMEs", Business and Management Studies, 3(2), 78-89.

Rauch, A., Wiklund, J., Lumpkin, G.T. ve Frese, M. (2009), "Entrepreneurial Orientation and Business Performance: An Assessment of Past Research and Suggestions for The Future", http://www.blackwellpublishing.com/journal.asp?ref=10422587\& site $=1$, (Erişim: 29.12.2019).

Resmi, S.İ., Begum, N.N. ve Hassan, Md.M. (2018), “Impact of CSR on Firm's Financial Performance: A Study on Some Selected Agribusiness Industries of Bangladesh", American Journal of Economics, Finance and Management, 4(3), 74-85.

Standing, C. ve Kiniti, S. (2011), "How can organizations use wikis for innovation?", Technovation, 31, 287-295.

Şanal, M. ve Girenay, D. (2019), "Risk Alan Proaktif Çalı̧̧anların Firma Performansına Etkisi Üzerine Bir Araştırma", Turkish Studies Economics, Finance, Politics, 14(1), 141-152.

T.C. Sanayi ve Teknoloji Bakanlığı. (2018), https://btgm.sanayi.gov.tr/ Handlers/DokumanGetHandler.ashx?dokumanId=bcf24389-c3c0-462883aa-73750e2a2baf (Erişim: 04.10.2018).

Ünal, T. ve Seçilmiş, N. (2014), "Satış Hasılatı Artışında AR-GE'nin Rolü ve Karlılı̆̆ın AR-GE Harcamalarına Etkisi: Gaziantep Örneği”, Yönetim ve Ekonomi Araştırmaları Dergisi, 22, 202-210.

Wiklund, J. ve Shepherd, D. (2005), "Entrepreneurial orientation and small business performance: a configurational approach", Journal of Business Venturing, 20, 71-91.

$\mathrm{Xu}$, J. ve Jin, Z. (2016), "Research on the Impact of R\&D Investment on Firm Performance in China's Internet of Things Industry", Journal of Advanced Management Science, 4(2), 112-116. 